\title{
The Severe Criminal Punishment of Drug Consumers in Albania. A Call for Reasonability and Reflection
}

\author{
Aleks Nikolli \\ European University of Tirana \\ Email: alnikolli@live.com
}

\section{Doi:10.5901/mjss.2015.v6n2p27}

\begin{abstract}
The opening and Europeanization process of Albanian society could not have happened without the influence of western societies' contagions, one of which is the consumption of narcotics. In the hope that this contamination could be prevented, the Albanian Legislator enacted severe criminal sanctions, not only for cultivation, production or the dealing of narcotics, but also for the possession of small quantities for personal use. This study aims to assess whether the severe sentences provided for drug possession in Albania have managed to curb the increasing tendency of this offence, using annual statistics published by the Ministry of Justice in Albania as the basis for the study. Since this study concluded that the application of severe sentences has not achieved the intended results to reduce the use of narcotics, we believe that the time has come to thoroughly rethink the fight against drugs in Albania and especially the approach towards the consumers.
\end{abstract}

Keywords: Severe sentence, punishment, drug possession, deterrence, Albanian Penal Code;

\section{Introduction}

Efforts to stop, or at least reduce, the consumption of narcotics are a challenge for many countries around the world, who have adopted different measures and mechanisms to achieve these objectives according to the extent of such phenomena, their economic and democratic levels and the historical and cultural peculiarities of the respective societies (Rosmarin and Eastwood, 2013, p. 9). There is no doubt that one of the earliest mechanisms and one that, above all, the majority of countries still believe in today in the effective fight against narcotics is penal measures. While politicians around the world, to avoid being labelled "soft on crime", are increasingly championing sentencing severity (Frase, 2001, p.263), criminological research over several decades and in various countries has generally concluded that enhancing the certainty of punishment produces a stronger deterrent effect than increasing the severity of the punishment (Von Hirsch, et al., 1999; 2009, p. 57).

In Albania the offence of selling or importation of drugs has existed since the first Criminal Code of 1928, in article 358. With the political changes of the 90s, after the massive emigration of the younger generation and the opening of Albanian society to western societies, came the first cases of narcotics users. Over the years, the increasing number of narcotics users has brought with it people who are willing to provide and to deal in them, thus establishing a market for narcotics in Albania. With the aim of preventing the spread of offences related to narcotics, the Albanian Legislator enacted severe criminal sanctions, not only for production, trafficking or dealing in narcotics but also for possession of small quantities of drugs for personal use. Article $283 \S 1$ of the Albanian Penal Code makes the selling, transportation, or possession of narcotic substances liable for prison sentences of 5-10 years and, further, in the second paragraph of the article, when this offence is committed in complicity or more than once the sentence can be imprisonment of 7-15 years.

The aim of this study is to analyse whether the application of severe sentences regarding drug possession for personal use in Albania has served as an effective tool that meets the general deterrent function of a penal sanction. If the severe criminal sentences have not served to stop or reduce the use of drugs (which cannot be done without possessing it) we believe that the time has come to change the approach on the fight against drugs in Albania, especially regarding the criminalization of possession of small amounts of drugs for personal use.

\section{Methodology}

After a fast historical development of drug offences in Albania, we will give a view of the actual legal framework regarding the criminalization of drug possession in Albania. Then to better understand the severity level of penal measures against 
narcotics foreseen in the Albanian criminal code, we will be comparatively considering some of the penal legislation of other countries in the region. Even though this comparison is difficult from a methodological aspect it is still possible to identify big differences between the criminal approaches of the legislation of Albania, Greece, FYROM (Macedonia), Kosovo, Montenegro and Italy. We have chosen the penal legislations of these countries not only because of cultural and socio-economic similarities, but also because none of them is noted for a mild approach towards drug related offences.

To conduct this study, statistical data published by the Albanian Ministry of Justice on narcotics-related offences committed in the years 2004-2012 was used (secondary data). Even though the increasing incidence of the offences of "Selling, transportation and possession of narcotics", foreseen by article 283 of the Criminal Code, is quite clear, the correlation between the number of people sentenced for such offences and the sentences stipulated for them could be influenced by the potential impact of the effectiveness of the police and prosecution office in following up these cases. Being aware of the limitations of these statistical data, to support our conclusion, we also used other secondary data regarding the incidence of drug users in Albania. The results of recent studies conducted in Albania regarding prevalence of consumption of narcotic substances and its spread over the years provide strong evidence to support our view. The total number of all adults who have ever tried any kind of illicit drug was estimated in 1995 to be around 5,000, while the current estimated figures oscillate between 40,000 and 60,000.

\section{Overview of the Albanian Criminal Legislation on Narcotics}

Offences in the field of narcotics initially appeared in the Albanian criminal legislation as early as the Penal Code of the Albanian Kingdom of 1928, which was influenced by the western criminal codes (Frashëri, 2013). In the second part of the Penal Code, article 358 provided for a sentence of 1 month to 1 year's imprisonment and a penalty of 100 to 1000 gold francs for anyone who brought in or sold opium, morphine, cocaine or marijuana in Albania without government permission.

In the criminal code of 1952, possession of narcotics came under article 284 "Preparation and trading of poisoning substances" and introduced a sentence of corrective work or imprisonment of up to 1 year for the possession of narcotics with the aim of selling, and for the trading of cocaine, opium, morphine, marijuana and other narcotics without a proper licence. The acts covered by the above paragraph, when habitually committed, carried a sentence of imprisonment of up to 3 years.

Likewise, in the Penal Code of 1977 narcotics possession was foreseen and was covered in article 134 under "Preparation or dealing in narcotics and other poisoning substances". In paragraph 2 of the article it states: "Preparation, possession or selling of narcotics without permission will be sentenced with re-education through labour or with imprisonment of up to ten years."

In the new Penal Code of 1995 (approved by law no 7895 dated 27.01.1995) four criminal provisions were enacted which made narcotics-related actions punishable, namely, article 283 "Production and selling of narcotics"; article 284 "Cultivation of narcotic plants"; article 285 "Possession of equipment for the production of narcotics"; and article 286 "Promotion of drug use". Later these provisions were amended and modified, and in the current Albanian Penal Code there are thirteen articles concerning narcotics. Of these provisions the most crucial ones are article 283, "Selling, transportation and possession of narcotics" (modified), article 283/a "Trafficking of narcotics", article 284 "Cultivation of narcotic plants", and article 284/c "Production and manufacturing of narcotics and psychotropic substances".

Although this study discusses penal measures in general regarding offences in the field of narcotics, its main focus is article 283 of the penal code ${ }^{1}$ and specifically the possession of narcotic substances for personal use. As can be observed from the content of this provision, although it covers a number of different related actions, essentially they can be summarized by the following three categories; 1) selling (to also include giving, dealing and trading); 2) transportation (which includes sending and delivery); and 3) possession (which includes taking, obtaining or acquiring drugs in any form).

Regarding the possession of narcotics for personal use, the High Court in the United Chambers gave a ruling on 27th March 2008 with a finding of guilty for the defendant, E.Z., (an addicted heroin user for at least 4 years), having been found in possession of 1.9 grams of powder containing heroin, on 22nd September 2005. According to the specialist

\footnotetext{
1 This article has a detailed description determining that: "Selling, offers to sell, giving or taking in any form, distribution, trading, transport, shipping, delivering, and keeping except cases when it is for personal use and in small doses of narcotic and psychotropic substances and seeds of narcotic plants, in violation of the law or in excess of their content, is punishable by imprisonment of five to ten years. The same act, if committed in complicity or more than once, shall be punishable by imprisonment of seven to fifteen years. Organizing, managing or financing this activity will be sentenced with ten to twenty years of imprisonment."
} 
toxicologist, referred to as an expert in court, the quantity of narcotic substances that the defendant possessed was sufficient to be for his own use, over a period of 24 hours.

The United Chambers of the High Court stated that:

"...The quantity of 1.9 grams of this substance would be not only for one usage, but for several during the day, thus suggesting that the defendant E.Z. had available, at the time of his arrest, several small doses which was for more than one usage over 24 hours .....".

In making their ruling the High Court interpreted the term "small doses" in article 283 to mean a quantity for a single usage, and therefore as E.Z. was in possession of a quantity deemed by the expert toxicologist to be sufficient for multiple usage over the course of the 24 hours, albeit for his own personal use, he could not avoid prosecution under this article as he had more than one "small dose". What the High Court did not consider in the determination of doses for personal use is the fact that narcotic substances are not goods that can be easily provided as you might buy cigarettes, and often, for convenience, consumers may purchase quantities to consume twice, three times or more.

Further, the High Court took a very narrow interpretation of article 283 regarding the term "small doses". The article clearly indicates that there should be allowance for the possession of a few small doses, providing it is for personal use, whereas the High Court took it to mean just a single dose, so if the defendant keeps more than a single dose they can be prosecuted and found guilty. In making this ruling the High Court stated that "such a definition of the notion 'in small doses', with the effect of executing article 283 of the Criminal Code, besides the preventive role that it plays in protecting the health of addicted drug users, has a role of general prevention in the fight against the phenomenon of the illegal usage of such substances". This suggests their clear intention to use harsh sentencing measures against even personal users as a deterrent against the widespread use of drugs.

In the third section we attempt to examine whether the above High Court ruling has served to reduce the number of drug consumers in Albania or whether it has just contributed to an increase in the number of drug users who are arrested and sentenced according to article $283 \S 1$ of the Criminal Code.

\section{A Comparative View of the Surrounding Countries' Criminal Sanctions Related to Narcotic Offences}

To better understand the severity of punishment provided by the Albanian Penal Code for acts of possession, transportation and dealing in narcotics, in this section we will take a comparative view of the legislation of several countries in the region, namely Greece, FYROM (Former Yugoslavian Republic of Macedonia), Kosovo, Montenegro and Italy.

In the criminal legislation of all the countries in this survey, there are provisions concerning possession, dealing, cultivation, production and international trade of drugs (trafficking). Apart from Greece none of the other countries penalize the use of narcotics (Dedovic, 2013, p. 225). Furthermore, in the national legislation of these countries, only the Italian legislation makes the distinction between "soft" and "hard" drugs. These will be discussed in turn.

In article 300, the Criminal Code of Montenegro (2010) provides for the offences of unauthorized production, keeping and releasing into circulation of narcotic drugs. After the amendments of May 2010 the Criminal Code of this country prescribed seven paragraphs to article 300 . Referring to the first paragraph, anyone who unlawfully produces, transports, sells, or keeps narcotic drugs or plants containing such substances may be punished with a prison sentence ranging from 2 to 10 years. Personal drug use is not sanctioned by the Criminal Code of Montenegro, nor is drug possession for personal consumption (Dedovic, 2013, p. 225), whereas the trafficking of narcotics (anyone bringing substances into Montenegro proclaimed to be narcotic drugs) shall be punished by a prison sentence of 2 to 12 years (paragraph 2). Paragraph 5 stipulates that the perpetrators of offences referred to in paragraphs 1 to 4 of this article who reveal the supplier of the drugs may be released from the penalty.

As in Montenegro, in the Criminal Code of Macedonia (2009) these offences are described under heading 21 "Crimes against human health" in two articles, "Unauthorized production and release for trade of narcotics, psychotropic substances and precursors" (article 215) and "Enabling the taking of narcotics and precursors" (article 216). According to the first paragraph of article 215, anyone who without authorization produces, sells keeps, transports, or in some other way releases narcotics for trade shall be punished with imprisonment of 3 to 10 years. However, if the offence referred to in paragraph 1 is committed with the use of narcotic drugs of a lesser quantity, the perpetrator shall be imprisoned for a period of between 6 months and 3 years. If this crime is committed in complicity or through organized crime the perpetrator shall be punished with imprisonment of at least 5 years.

Under the Greek Codification of the Drug Legislation CDL (Law 3459/2006) articles 29-30, drug offenders are 
assessed as either addicted or non-addicted. Drug use is only an offence when the user is a non-addict (EMCDDA, 2012). Addicted users cannot be criminally prosecuted, but they are mandated to have treatment for up to 1 year at a detoxification centre. Transport, sale, and production are the offences associated with the concept of drugs trafficking in Greece, where the penalties envisaged are among the heaviest in Europe (DrugScience, 2013). The basic penalty for illicit drug trafficking according to article 20 of the new Law 4139/2013 on Addictive Substances that amended the earlier $C D L$, ranges from 8 to 20 years with pecuniary fines rising to $€ 300,000$. Additionally, according to the innovative article 21 of the new law, imprisonment of no more than 3 years is the penalty for trafficking of small drug quantities by drugdependent perpetrators in order to cover their individual needs, or for giving out to acquaintances for their individual needs without profit. There is a maximum penalty of 6 months imprisonment for possessing drugs, or cultivation of cannabis with a view to using it.

Formally the first paragraph of article 73 of the Italian DPR of 9th October 1990, n. 309 updated with law no. 49 (2006), provides a severe punishment with imprisonment of 6-20 years for any person who, without the authorization referred to in article 17, cultivates, produces, sells, distributes, transports, procures for others, or sends for any purpose the narcotic or psychotropic substances listed in Table I of the Code as hard drugs, while for the soft drugs included in Table II of the Code (e.g. cannabis), the punishment is a prison sentence of 2-6 years. Paragraph 5 provides that if the means, the mode or the circumstances of the action, or the quality and quantity of the substances are deemed to be mild or less serious, the penalties applied shall be imprisonment of 1-6 years and a fine of $€ 3,000$ to $€ 26,000$. Drug use is not an offence in Italy, nor the possession of drugs below the user's average daily intake amount; it may result in simply a warning or administrative penalty (suspension of the driver's licence for example).

In the Republic of Kosovo Criminal Code (2013), drug offences are covered in Chapter XXIII "Narcotic drug offences", in articles 273-283. Briefly, according to the first paragraph of article 273 , whoever purchases or possesses narcotic drugs with the intent to sell or distribute them shall be punished by imprisonment of 2-8 years. The second paragraph stipulates a punishment by imprisonment of 2-12 years for whoever distributes, sells, transports, delivers, brokers or dispatches narcotic drugs. However article 279 of the Kosovo Penal Code (2013) provides for a prison sentence of 3-15 years for committing these criminal acts through organized crime with a large amount of narcotics, while for those who only possess narcotics, article 275 provides a sentence of a fine and imprisonment of 1-3 years. This article also provides a punishment by fine or imprisonment of up to 1 year for first-time keepers or for those who possess less than 3 grams of a narcotic substance for personal use.

As the newest code, the Criminal Code of Kosovo has followed the trend of some other European countries such as Switzerland, the Netherlands, Germany, and Portugal which have abrogated or softened the criminal punishment towards the possessors of such substances in small quantities for personal use.

Although it is very difficult to make a comparison of sentencing for such acts in these six countries including Albania (due to various notions and formulations used in their legislation), we have tried to present these data in Table 1.

Table 1. Table of comparative criminal sentences for drug offences in several countries of the region

\begin{tabular}{|c|c|c|c|c|c|c|}
\hline Country & Drug classification & Drug use & $\begin{array}{l}\text { Possession with a } \\
\text { view to use }\end{array}$ & $\begin{array}{c}\text { Supplying } \\
\text { drug to users }\end{array}$ & Selling, dealing & Huge quantities \\
\hline Montenegro & No & No & No & 2-10 years & 2-10 years & 2-12 years \\
\hline FYROM & No & No & No & $6 m-3$ years & 3-10 years & 5 years $\max$ \\
\hline Greece & No & formally & For non-addicts up to 6 months & $6 m-3$ years & $\begin{array}{l}6 \mathrm{~m}-3 \text { years } \\
8-20 \text { years }\end{array}$ & 8-20 years \\
\hline Italy & 2 categories & Administratively & Administratively & $1-6$ years & $1-6$ years & $\begin{array}{l}2-6 \text { years } \\
6-20 \text { years }\end{array}$ \\
\hline Kosovo & No & No & $<3 g$. up to 1 year $>3 g$ 1-3 years & $2-8$ years & $\begin{array}{l}2-8 \text { years } \\
2-12 \text { years }\end{array}$ & $3-15$ years \\
\hline Albania & No & No & $\begin{array}{c}\text { Over a single dose } 5-10 \text { or } \\
7-15 \text { years }\end{array}$ & $5-10$ or $7-15$ years & $\begin{array}{c}5-10 \text { or } \\
7-15 \text { years }\end{array}$ & $\begin{array}{c}7-15 \text { or } \\
15-38 \text { years }\end{array}$ \\
\hline
\end{tabular}

It can be seen from the table that for the possession of drugs for personal use (more than a single dose which in practice may be less than $0.5 \mathrm{~g}$ ), Albania stipulates a prison sentence of 5-10 years (and, regarding offences of complicity or more than one use, a sentence of 7-15 years). This comparison also shows that Albanian criminal legislation provides harsher sentences even for providing narcotic substances to others without profit or for small dealers in narcotics, first-time offenders or those who do it in order to fulfil their needs as users.

The potential for significantly higher minimum sentences under Albanian legislation has a direct effect on the 
concrete measures of sentences given by courts to less dangerous offenders or cases where there are certain mitigating circumstances.

\section{Effects of Severe Penal Sentences on the Prevention of Drug Possession in Albania}

One of the main purposes of a criminal sentence is general prevention (Terrance, Miethe and Lu, 2005, p. 20). The lawmakers were initially convinced that through severe punishment of people who violate the law, other people would learn from this and so would not repeat the same mistakes in the future (Doob and Webster, 2009). In relation to the case object of the study, the Albanian Legislator considered that through the severe sentences given to those who possess or deal in narcotic substances, the country could avoid the spreading of this social negative phenomenon.

The same confidence that through severe exemplary sentences the increase in drug consumers can be prevented has also been expressed by some Albanian authors and criminal law scholars (Elezi, 2007, p. 502; Qafa, 2013, p. 143). According to these, the criminal law and the severe sentences are a powerful weapon to combat such criminal acts. As with the above High Court ruling, these scholars uphold the opinion that legal changes in terms of aggravation of punishment measures made over the years will contribute to reducing the spread of these crimes.

However, earlier studies conducted in other countries have indicated that the fight against drugs merely through criminal measures has not only failed to prevent the increasing number of users of narcotic substances in the world, but also has contributed to the overcrowding of prisons (Stevenson, 2011, p. 2). As Stevenson states, as a result of the past drug policy, the number of people currently incarcerated worldwide is at an all-time high of 10 million. The clearest evidence to cast doubt on the deterrence efficacy of criminal laws is the American system of criminal law, where even though the offenders are severely sentenced, there still appear before the law courts many more criminals, even more than in the European countries with significantly lighter punishment measures (Whitman, 2005, p. 3). With the increase in criminological studies supporting the lack of the deterrent effect of criminal punishment, and the evolution of human rights standards, the science of modern criminal law treats the criminal sentence as a means of ultima ratio (Melander, 2013, $p$. 43). So the criminal sentence is neither the most humane tool that the state has in hand to fight criminality, nor the most effective tool to achieve such a result.

As a follow-up to this study we examine the relation between the application of harsh sentences and the reduction or control of criminality in the field of narcotics in Albania, especially concerning possession of drugs in small quantities. This is based on statistical data published by the Albanian Ministry of Justice regarding the number of people convicted under article 283 of the Albanian Criminal Code. To give a general overview of the criminality trends regarding narcotic offences under article 283 , the numbers of people convicted for other offences related to narcotic substances are also presented. See Figure 1 below:

Figure 1. Trends of conviction for the main drug offences in the years 2004-2012 in Albania

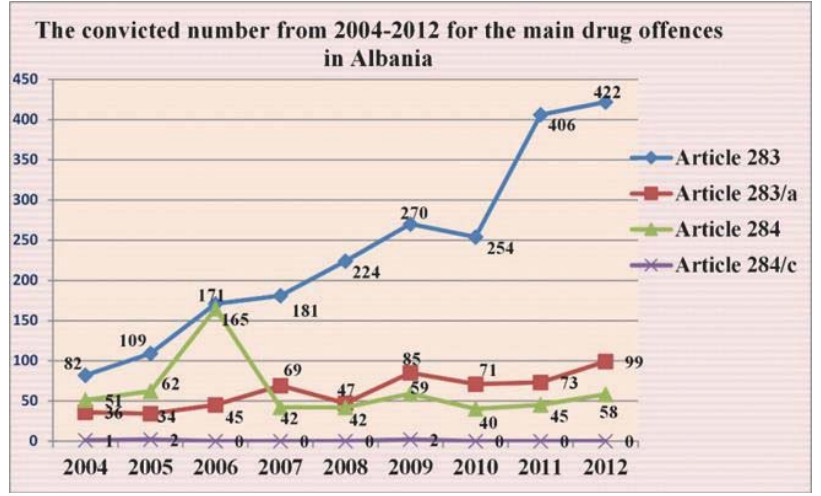

Source: Statistical data published by the Albanian Ministry of Justice

The above data show that for the offence of "Selling, transportation and possession of narcotics" (article 283), between 2004 and 2012 there was an increase of 515\% in the number of convictions in the district courts, from 82 to 422 ; and for the offence of "Trafficking of narcotics" (article 283/a), between 2004 and 2012 there was an increase in convictions from 36 to 99 . 
From the above data it is clear that the penal convictions have had a visible impact as regards the offence of "Cultivation of narcotic plants", under article 284 of the Criminal Code, but it has not had the expected impact regarding the offence of "Selling, transportation and possession of narcotics", provided by article 283 of the Code. The paradox of this impact can be seen if one considers the fact that for the offence of "Cultivation of narcotic plants" the Albanian Criminal Code provides a milder sentence than for the offence of "Selling, transportation and possession of narcotic substances". An explanation for this effect would be that the offence of "Cultivation of narcotic plants" is much easier to detect than the offence of "Selling, transportation and possession of narcotics". Cultivating a narcotic plant such as cannabis sattiva for 5 months, which grows up to 2 metres high, is much more easily discovered than keeping 5 grams (or 500 grams in the case of marijuana, heroin or cocaine) in a pocket, car or building. On the other hand the lack of deterrent effect of the criminal sentence for the possessors of narcotic substances for personal use may have a simple explanation. If a consumer is not scared of the certain damage that the drug will cause to their health, there is no way that they will be scared by an uncertain criminal punishment (in case of non-disclosure or failure to be arrested, or if they do not understand that they are violating the law with this action).

Even though the increasing incidence of the offences of "Selling, transportation and possession of narcotics", foreseen by article 283 of the Criminal Code, is quite clear, the correlation between the number of people sentenced for such offences and the sentences stipulated for them could be influenced by the potential impact of the effectiveness of the police and prosecution office in following up these cases. So it could be questioned whether the increasing number of cases of people arrested and criminally charged has come as result of more people committing such offences or as a result of the improved police performance or the expansion of criminalization to less serious activity, which in the past has not been the focus for the police or prosecution service. We believe that these two variables might have influenced the cases covered by article 283/a of the Criminal Code (Trafficking of narcotic substances), but we doubt that they would have influenced the increasing number of people sentenced under article 283 of the Criminal Code, which is object of our study.

The results of recent studies conducted in Albania regarding prevalence of consumption of narcotic substances and its spread over the years provide strong evidence to support our view. The total number of all adults (aged 15 to 64 years) who have ever tried any kind of illicit drug was estimated in 1995 to be around 5,000 (lifetime prevalence of $0.2 \%$ ) and 10,000 (lifetime prevalence of 1.0\%) in 1998 (Kakarriqi and Sulaj, 2000), while the current estimated figures according to the European Monitoring Centre for Drugs and Drug Addiction (EMCDDA, 2013) oscillate between 40,000 and 60,000 (lifetime prevalence of between 2.0\% and 2.8\%) - a substantial increase since 1995. Among these, according to Zihni Sulaj, director of the toxicology centre at the University Hospital in Tirana (Sulaj, 2014) there are estimated to be around 10,000 to 15,000 problematic drug users in Albania.

These published survey data on the fast-increasing number of drug consumers in Albania suggest that the increasing number of people being sentenced under article 283 of the Penal Code is precisely due to this fact and not any performance improvement by the police or prosecution service.

What should be emphasized is that in a recent survey of judicial jurisprudence regarding article 283 of the Albanian Criminal Code it was noted that, in $66 \%$ of cases (62\% under the paragraph 1 provisions and $4 \%$ under paragraph 2 of the article), defendants are only found guilty of possession of small quantities of drugs for personal use, mainly cannabis (Nikolli, 2014). Thus, the severe punishment for drug consumers is not curbing the increase of their numbers, but is in fact contributing to the overpopulation of Albanian prisons which are already overcrowded. In just 16 months, the Albanian Parliament has approved two amnesties, as a result of which about 1,000 convicted people have been released from prison (law no. 2012 and law no. 2014).

We have not managed to find any studies that indicate the ratio of people sentenced for drug offences in relation to the total number of convicted people, but from the data of the General Department of Prisons (2013), during 2012 there were a total of 4,850 prisoners in Albania and, based on the above data in the years 2010, 2011 and 2012, Albanian courts sentenced over 1,500 people. Considering that part of a convicted defendant's imprisonment sentence can be suspended, but that the majority of them receive prison sentences from 3 to 10 years (in some cases even more), we estimate that the number of people convicted for drug offences in Albanian prisons in 2012 was over 1,000 people, or more than $21 \%$ of the total number.

The severe sentences of 5-10 years' imprisonment stipulated (by article 283) for the consumers of narcotic substances are not in compliance with either retribution theories and just deserts, or with deterrence, and much less the goal of rehabilitation. The consumption of narcotic substances is a great plague on modern societies, however the consumers do not cause such great harm to others to warrant such severe sentences. Criminalizing drug possession for personal use with such severe penalties seems not to fit with the claims that punishment awaits only those who harm or endanger the legal interests of third parties, and is not applicable in cases of self-harm. Even if we consider that the 
possessors of drugs may pose a potential threat for society (because possessors may sell or offer it to others, or drug users may in some cases endanger public safety), the quantum of punishment stipulated by article 283 of the penal code is totally disproportionate to this eventual uncertain threat (Bentham, 2009, p. 54).

Furthermore, prison is not the most suitable place to educate, treat and rehabilitate the users of narcotics. Drugs have always been present, and it seems they always will be. Therefore, we must control and manage them to minimize their risk for society, though we might never succeed in totally eliminating them. The 13 year old Portuguese decriminalization model and its encouraging results (Rolles and Eastwood, 2012, p. 161) should be considered seriously by the Albanian Legislator as a good example of how society can deal with the drug use without the application of severe penal measures. Preventing drug use before it begins and trying to rehabilitate the users is the most cost-effective, common-sense approach to promoting safe and healthy communities.

\section{Conclusions}

Based on the data of this study we consider that the severe criminal sentences are not serving as a deterrent to prevent possession and dealing of narcotic substances in Albania. Meanwhile, with milder sentences the Albanian state has managed to keep under control, and has even slightly contributed to a reduction in, narcotic plant cultivation (according to article 284 of the Criminal Code). Therefore the sentences of 5-10 years' imprisonment (and with regard to the second paragraph, 7-15 years' imprisonment) have not reduced the possession of quantities of 1, 10, or 100 grams of marijuana, while the sentences of 3-7 years' imprisonment have managed to prevent the cultivation of narcotic plants from which can be produced 20,200 or even $2,000 \mathrm{~kg}$ of marijuana. This clearly suggests that the severe penal sentences do not serve in all cases as an effective deterrent preventing the spread of certain types of crime, one of which is undoubtedly the possession of narcotic substances for personal use. Therefore, regarding the difficult question of how to stop drugs, we cannot continue to give the simple answer of sentencing consumers. As UNODC stated, for offences involving the possession, purchase or cultivation of illicit drugs for personal use, community-based treatment, education, rehabilitation and social integration represent a more effective and proportionate alternative to conviction and punishment (2012).

To conclude, modern criminal law should be reasonable and also human, but it appears from the results of this study that article 283 of the Albanian Criminal Code does not meet these criteria. This article hardly looks reasonable and even less so, human. Consequently we believe that the time has come to thoroughly rethink the fight against drugs in Albania and especially the approach towards the possession of small quantities for personal use.

\section{References}

Bentham, J., 2009. Punishment and deterrence. In: A. Ashworth, A. von Hirsch and J.V. Roberts, eds. Principled Sentencing: Readings on Theory and Policy. 3rd ed. Oxford: Hart Publishing, pp. 53-57.

Dedovic, V., 2013. Country Report Montenegro, Drug policy and drug legislation in south east Europe. pp. 219-237. Retrieved from: http://www.csd.bg/artShow.php?id=16678.

Doob, A. N. and Webster, C. M., 2009. Studies of the impact of new harsh sentencing regimes. In: A. Ashworth, A. von Hirsch and J.V. Roberts, eds. Principled Sentencing: Readings on Theory and Policy. 3rd ed. Oxford: Hart Publishing, pp. 71-75.

DrugScience, 2013. Greece, Drug trafficking and related crimes. Retrieved from: http://www.drugscience.org.uk/law/greecel. Accessed on 1 April 2014.

EMCDDA, 2013. Country overview: Albania. Retrieved from: http://www.emcdda.europa.eu/publications/country-overviews/al. Accessed on 8 April 2014.

EMCDDA, 2012. Illegal possession of drugs. Retrieved from: http://www.emcdda.europa.eu/html.cfm/index5749EN.html. Accessed on 8 April 2014.

Elezi, I., 2007. Criminal Law (Special Part.) Tirana: Erik Editions.

Frase, S. R., 2001. Comparative Perspectives on Sentencing Policy and Research. In: M. Tonry and R.S. Frase, eds. Sentencing and Sanctions in Western Countries. New York: Oxford University Press, pp. 259-292.

Frashëri, K., 2013. Eqerem Vlora, one of the greatest critics of Ahmet Zogu. Shqiptarja.com newspaper. 2 August 2013. Retrieved from: http://www.shqiptarja.com/dossier/2711/ eqerem-vlora-nje-nga-kritiket-me-te-medhenj-te-ahmet-zogut-170113.html. Accessed on 2 April 2014.

General Department of Prisons, Albania, 2013. Annual analyses for the year 2012. Retrieved from: www.dpbsh.gov.al/skedaret/ 1390820010-Analiza\%20.

High Court, Albania, 2008. The unifying decision of the United Chambers of the High Court no.1, 27.3.2008. Retrieved from: http://www.gjykataelarte.gov.al/previewdoc.php?file_id=125.

Kakarriqi, E. and Sulaj, Z., 2000. National report on the drug situation in Albania, PHARE Project on Drug Information Systems Bridging Phase, Brussels: European Commission. 
Melander, S., 2013. Ultima Ratio in European Criminal Law. Oñati Socio-legal Series 3(1), pp. 42-61. Retrieved from: http://ssrn.com/ abstract $=2200871$.

Ministry of Justice, Albania, 2004-2012. Annual statistics of Ministry of Justice for the years 2004-2012. Available at: http://www.drejtesia.gov.al/al/dokumente/statistika.

Nikolli, A., 2014. Empirical survey of the Albanian judicial practice on criminal offense of "Manufacturing and sale of narcotics," provided by article 283 of the criminal code. European Scientific Journal, June, 10 (16) pp. 307-321.

Qafa, F., 2013. Review of historical development in the Albanian criminal code of the narcotic problems. European Scientific Journal, January, 9 (1), pp. 137-151.

Rolles, S., Eastwood, N., (2012). Drug Decriminalisation Policies in Practice: A Global Summary. In: Global State of Harm Reduction 2012. Towards an integrated response. London. Pp.157-165.

Rosmarin, A. and Eastwood, N., 2013. A Quiet Revolution: Drug Decriminalisation Policies in Practice across the Globe. Retrieved from: http://www.opensocietyfoundations.org/ reports/quiet-revolution-drug-decriminalisation-policies-practice-across-globe.

Stevenson, B., 2011. Drug policy, criminal justice and mass imprisonment, Working Paper Prepared for the First Meeting of the Global Commission on drug policies, Geneva. Retrieved from: http://www.globalcommissionondrugs.org/wp-content/themes/gcdp_v1 /pdf/ Global_Com_Bryan_Stevenson.pdf.

Sulaj, Z., 2014. Interview for KLAN television. Retrieved from: https://www.youtube.com/watch?v=cKivqXaURrk. Accessed on 1 May 2014.

Terrance, D., Miethe, T. D. and Lu, H., 2005. Punishment. A comparative historical Perspective. Cambridge: Cambridge University Press.

UNODC, (2012). UNODC and the protection and promotion of human rights. Vienna: Retrieved from: http://www.unodc.org/documents /justice-and-prison-reform/UNODC_HR position_paper.pdf.

Von Hirsch, A., Bottoms, A., Burney E. and Wikstrom, P-O., 1999. Criminal Deterrence and Sentence Severity: An Analysis of Recent Research. Oxford: Hart Publishing.

Von Hirsch, A., Bottoms, A., Burney, E. and Wikstrom, P-O., 2009. Deterrent sentencing as a crime prevention strategy. In: A. Ashworth, A. von Hirsch and J.V. Roberts, eds. Principled Sentencing: Readings on Theory and Policy. 3rd ed. Oxford: Hart Publishing, pp. $5-64$.

Whitman, Q. J., 2005. Harsh Justice: Criminal punishment and the widening divide between America and Europe. New York: Oxford University Press.

\section{Legislation}

Albania. Criminal Code (1927), approved by Decree no. 83-1, dated 28.05.1927.

Albania. Criminal Code of the People's Republic of Albania (1952), approved by Law no. 1470, dated 23 May 1952.

Albania. Criminal Code of the Socialist People's Republic of Albania (1977), approved by Law no. 5591, dated 15 June 1977.

Albania. Criminal Code of the Republic of Albania (1995), approved by Law no. 7895, dated 27 January 1995, amended.

Albania. Law "For granting amnesty" (2012), approved by Law no. 107/2012, came into force on 28 November 2012. Published in the official bulletin no. 148, dated 21 November 2012.

Albania. Law "For granting amnesty" (2014) approved by Law no. 22/2014, came into force on 10 April 2014. Published in the official bulletin no. 38, dated 26 March 2014.

Montenegro. Criminal Code of Montenegro (2010), Podgorica. "Official Gazette of Montenegro" No 25/2010.

FYROM. Criminal Code of Macedonia (2009), consolidated version with the amendments from March 2004, June 2006, January 2008 and September 2009.

Greece. Codification of the Drug Legislation CDL Greece (2006), Law no 3459/2006, Athens, Government Gazette 103/25.5.2006.

Greece. Act of addictive substances and other provisions, Law no 4139/2013, Athens, Government Gazette 74/20.2013.

Italy. Italian law no. 49 of 21 February 2006, published in the Official Gazette no. 48 of 27 February 2006 - Ordinary Supplement no. 45.

Kosovo, Criminal Code of the Republic of Kosovo (2012) approved by Law no. 04/L-129, 20 April 2012, Pristina, Official gazette No. 19 I 13 JULY 2012. 